\title{
Fish, seabirds and trophic cascades in the Baltic Sea
}

\author{
Henrik Österblom ${ }^{1, *}$, Michele Casini ${ }^{2}$, Olof Olsson ${ }^{3}$, Anders Bignert ${ }^{4}$ \\ ${ }^{1}$ Stockholm University, Department of Systems Ecology, 10691 Stockholm, Sweden \\ ${ }^{2}$ Swedish Board of Fisheries, Institute of Marine Research, PO Box 4, 45321 Lysekil, Sweden \\ ${ }^{3}$ Mistra, Gamla Brogatan 36-38, 11120 Stockholm, Sweden \\ ${ }^{4}$ Swedish Museum of Natural History, Contaminant Research Group, PO Box 50007, 10405 Stockholm, Sweden
}

\begin{abstract}
In the relatively simple Baltic Sea ecosystem, zooplankton-feeding sprat Sprattus sprattus is a major food source for breeding seabirds and piscivorous fish, and an important resource for commercial fisheries. Large-scale and long-term ecosystem changes resulting mainly from over fishing and recruitment failure of cod Gadus morhua, which is the main fish predator of sprat, have affected natural-history patterns in a piscivorous seabird, the common guillemot Uria aalge, in a complex way. As the sprat stock increased, leading to lower energy content of fish, common guillemot chick body mass at fledging decreased. However, chick fledging body mass recovered in recent years as the sprat stock diminished, which brought about corresponding increases in sprat weight-at-age and energy content. The cod and sprat fishery affect the common guillemots in the Baltic Sea, but the effects differ depending on the management strategy.
\end{abstract}

KEY WORDS: Cod · Baltic Sea · Fisheries management - Gadus morhua - Common guillemot · Sprat · Sprattus sprattus $\cdot$ Trophic cascade $\cdot$ Uria aalge $\cdot$ Junk-food hypothesis

Resale or republication not permitted without written consent of the publisher

\section{INTRODUCTION}

The ecosystem approach to fisheries management is intended as a step towards sustainable use of marine ecosystems; however, this can be complicated. The cod Gadus morhua stock in the Baltic Sea collapsed in the late 1980s, resulting in a 4 -fold increase in the abundance of sprat Sprattus sprattus (the main prey of cod), which reached a peak in 1996 (ICES 2005a). During this period, zooplankton biomass decreased (Möllmann \& Köster 2002), mostly due to sprat predation (Casini et al. 2006). In response, fishery management allowed the sprat fishery to increase more than 5-fold during the 1990s. This increased fishing mortality exceeded the defined precautionary level in 1997-98, and the abundance of sprat (and catch) decreased despite above-average recruitment during several years (ICES 2005a). Currently, the stock is characterized as being within safe biological limits. The stock of other common zooplanktivorous fish species, e.g. herring Clupea harengus, has decreased continuously since the 1970s (ICES 2005a). Environmental variables (e.g. spring water temperatures and ice coverage) are important in determining recruitment of the sprat and herring stocks in the Baltic Sea (Axenrot \& Hansson 2003, MacKenzie \& Köster 2004, ICES 2005a), but available evidence indicates that fishing mortality is an important driver for the development of these clupeid stocks in the region (ICES 2005a). The clupeids (sprat and herring) are, with cod, the main target species in the Baltic Sea fisheries (ICES 2005a). We show here that alternative ways to manage stocks of sprat and its main predator (cod) in the Baltic Sea result in opposing cascading effects on a regionally vulnerable seabird: the pursuit-diving common guillemot Uria aalge.

Cairns (1987) predicted that seabird breeding parameters should vary with food supply, and a number of long-term studies have correlated food supply to breeding and other demographic parameters (Sydeman et al. 1991, Ainley et al. 1995, Anker-Nilssen et al. 1997, Oro \& Furness 2002, Oro et al. 2003). However, environmentally driven changes, e.g. climate-related effects on timing of breeding and thereby breeding success and chick growth and condition (Bertram et al. 
2001, Davoren \& Montevecchi 2003, Gjerdrum et al. 2003), buffering mechanisms (e.g. diet switching) and variation in predation pressure, generally complicate the interpretation of data (Furness 2003). Theory predicts that surface-feeding seabirds are more sensitive to changes in food supply than pursuit-diving seabirds (e.g. common guillemots), and there is also some empirical support for this (Furness 2003). However, pursuit-diving species may also be very sensitive to changes in food supply (e.g. Ainley 1977). The common guillemot is a highly specialized feeder and a single-prey loader (Bradstreet \& Brown 1985), i.e. when provisioning their chick, only a single prey item is brought to the chick by a parent. Thus, the size (energy content) of that prey item is important. The vulnerability of pursuit-diving species can be illustrated by, e.g., an unprecedented breeding failure of common guillemots in the North Sea in 2004, likely due to a drastic reduction in the energy content of their prey (Wanless et al. 2005).

We used a unique, long-term data-set on a seabird that feeds almost exclusively on sprat (Hedgren 1976, Lyngs \& Durinck 1998) to investigate its response to the long-term changes in the Baltic Sea fish community. In Österblom et al. (2001), we previously reported the first part of this study: how the birds responded in a counter-intuitive way (decreased fledging body mass) to the increasing sprat stock. Now we provide the second part, which strengthens our previous conclusions and illustrates a response of the birds to the decreasing sprat stock.

\section{MATERIALS AND METHODS}

Stora Karlsö $\left(57^{\circ} 17^{\prime} \mathrm{N}, 17^{\circ} 58^{\prime} \mathrm{E}\right)$ has the largest breeding colonies of common guillemots in the Baltic Sea, and is likely to be a source area for the population in the region. Ringing data show that common guillemots disperse from this island to other colonies in the Baltic (Lyngs 1992). Data on mean body mass of common guillemot fledglings at Stora Karlsö were collected in 1972 to 1976 (Hedgren 1979), 1989 and 1991 to 2004. The number of chicks ringed and weighed varied among years, with an average of 1179 chicks (range 208 to 3314, except for 1996 when only 46 chicks were ringed and weighed due to less ringing activity). In the regression analyses, annual mean chick weights were assigned loads relative to the number of chicks that were weighted that year. Chick fledging mass was used as an indicator of chick condition, and all chicks included in the study from 1989 to 2004 were weighed at or near the median fledging date. Hedgren (1979) found that mean body mass of chicks fledging at Stora Karlsö decreased by an aver- age of $2.6 \mathrm{~g} \mathrm{~d}^{-1}$ after the median fledging date. Thus, chicks fledging early or in the peak of the fledging season weighed more than those fledging later. To decrease the effects of a lower mean fledging body mass due to this seasonal variation, chicks weighed after 4 July were excluded from the sample between 1989 and 2004. We only had access to mean fledging weights during the 1970 s, and were unable to make this correction for these data. However, the vast majority of weight data from 1972 to 1976 were obtained under similar conditions (Hedgren 1979), and there was no difference in age at fledging between 1975 and 1998 (Österblom \& Olsson 2002), indicating that data from these 2 time periods were sufficiently comparable for our analysis.

Hedgren (1976) and Lyngs \& Durinck (1998) illustrated that a large proportion (>90\%) of common guillemot chick and adult diet consists of sprat. In 1998, 96.5\% of all fish brought to chicks at Stora Karlsö were identified as clupeids, presumably sprat (Österblom \& Olsson 2002). Analogous observations were made in 2002 and in 2004, i.e. 98.3 and $91.7 \%$ clupeids, respectively (authors' unpubl. data). We thus assume that chick diet mainly consisted of sprat throughout the study period.

We used data on abundance and mean weights of sprat for the period 1974 to 2004 in the central Baltic Sea (ICES 2005a). The mean weight of sprat was calculated from commercial landings obtained throughout the year, and the overall mean was calculated for each age class (M. Cardinale pers. comm). The mean weight of sprat of different age-classes shows similar time trends (ICES 2005a) and we primarily used the mean weight of age 4 sprat in our analyses, because the mean weight of sprat consumed by common guillemot chicks at Stora Karlsö during the 1970s (13.3g; Hedgren 1976) was similar to the mean weight of age 4 sprat during that time period (13.4 g: ICES 2005a). However, we also used information from age-classes 2 , 3 and 5, as field observations during recent years indicate that these age-classes also can be important in the chick diet (authors' unpubl. data).

To assess possible confounding relationships with physical factors, we used linear regression analysis to investigate the relationship between common guillemot mean fledging mass as a dependent variable and the NAO (North Atlantic Oscillation) index (J. Hurrell unpubl. data, available at www.cgd.ucar.edu/cas/ jhurrell/indices.html) between 1972 and 2004, which is a climate index correlated to Baltic Sea ice cover and water temperature during spring (MacKenzie \& Köster 2004), as the independent variable. We also used anomalies from the long-term average air temperature in February to May and also in June as independent variables, during the same time period. Hedgren (1979) 
found that pre-breeding climatic condition for adults (February to May) affected the timing of breeding (i.e. warm spring = early breeding) during the 1970s, and fledging body mass during the 1990s was negatively correlated with deviations from long-term average air temperature in June (Österblom et al. 2001). Air temperatures were from Visby airport (the nearest weather station) and were provided by the Swedish Meteorological and Hydrological Institute. Long-term average air temperatures were determined from 1961 to 1990.

In order to assess the importance of different drivers affecting the sprat stock dynamics, we used data on the relative proportions of predation and fishing mortality for sprat in the central Baltic, estimated by Multispecies Virtual Population Analysis (MSVPA) (ICES 2005b). We did not include predation pressure from birds in this analysis of mortality for sprat, due to limited knowledge on the dynamics of the common guillemot population in the area. Available estimates indicate that the assumed 40000 individuals of common guillemots consume $5000 \mathrm{t}$ sprat $\mathrm{yr}^{-1}$, which is less than $5 \%$ of cod predation and the commercial fisheries landings, (Lyngs \& Durinck 1998). The common guillemot is likely to be one of the most important avian predators of sprat in the region.

\section{RESULTS}

The large-scale changes in the Baltic Sea fish community, with peaking abundance of sprat in the mid1990s (Fig. 1) and a subsequent decrease in abundance, is reflected in the fledging mass of the sprat-feeding common guillemot (Fig. 2). In addition to our previously reported decrease in fledging mass as a response to the decreased weight-at-age of sprat (Fig. 2), we here show how the birds' fledging mass increased as a response to the recent increase in sprat weight-at-age. There was a significant negative correlation between common guillemot fledging body mass and the abundance of age 4 sprat $\left(p<0.04, r^{2}=0.24\right.$, Fig. $3 \mathrm{~A})$, as well as between fledging body mass and the sum of the abundance of sprat in age-classes 2 to 5 $\left(\mathrm{p}<0.04, \mathrm{r}^{2}=0.24\right)$.

The qualitative changes in sprat (weight-at-age) was the result of changes in the abundance of sprat, i.e. the mean weight of sprat at a given age (e.g. age 4) was significantly negatively correlated with the total abundance of sprat ( $p<0.0001, r^{2}=0.49$, Fig. 3B) between 1974 and 2004. Our study indicates that these qualitative changes affected common guillemot fledging body mass, as there was a significant positive correlation between the mean weight of age 4 sprat and common guillemot fledging mass between 1974 and 2004 (p < $0.001, r^{2}=0.55$, Fig. 3C). The correlation was also sig-

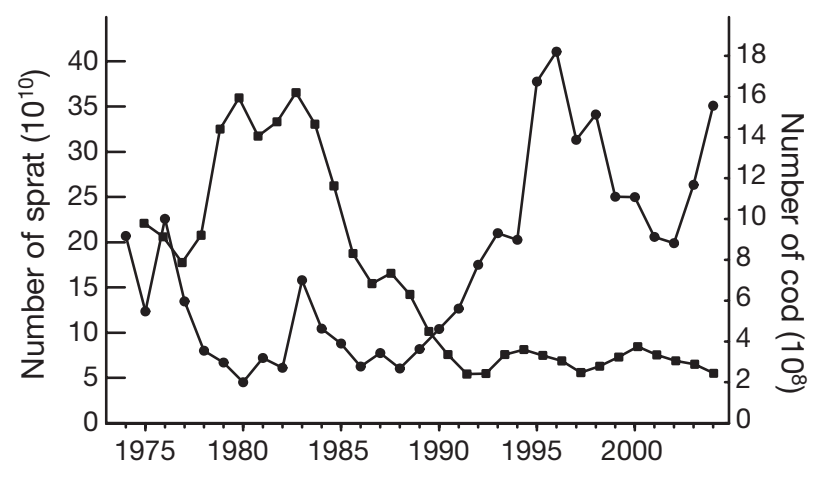

Fig. 1. Gadus morhua and Sprattus sprattus. Total abundances (all age-classes) of cod ( $\bullet$ ) and sprat $(\bullet)$ in the Baltic Sea between 1974 and 2004 (data from ICES 2005a). Sprat increase in 2003 and 2004 was due to large recruitment in those years (ICES 2005a)

nificant when the body mass of other age classes was used (age 2: $\mathrm{p}<0.03, \mathrm{r}^{2}=0.26$; age $3: \mathrm{p}<0.02, \mathrm{r}^{2}=0.34$; age 5: $p<0.001, r^{2}=0.52$ ). We found no significant correlations between common guillemot fledging mass and abiotic variables, i.e. there was no significant correlations with the NAO index $\left(\mathrm{p}<0.07, \mathrm{r}^{2}=0.17\right)$ or with anomalies from long-term average air temperatures between February and May $\left(p>0.1, r^{2}=0.00\right)$ or June $\left(p>0.1, r^{2}=0.07\right)$. These results indicate that fledging mass of common guillemot chicks was not affected by climate-mediated changes in timing of breeding, or by direct effects of weather on the mass of the chicks. Instead, this study indicates that changes in the mean weight of sprat, mediated by changes in sprat abundance, had an effect on common guillemots.

The decrease in cod in the late 1980s (Fig. 1) led to a rapid increase in sprat (Fig. 1, ICES 2005a). As a consequence, since the early 1990s, sprat fishing mortality has increased (ICES 2005a) and is currently higher than predation mortality (Fig. 4).

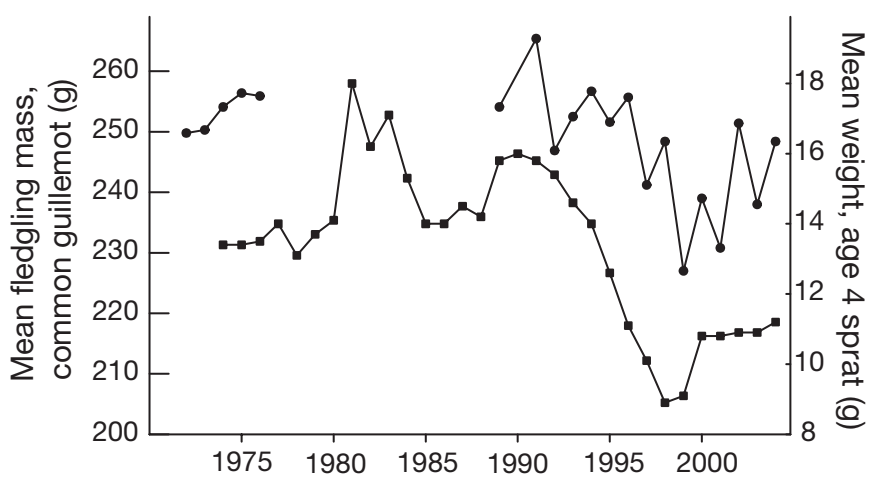

Fig. 2. Uria aalge and Sprattus sprattus. Mean fledgling mass of common guillemot during 1972-1976 and 1989-2004 (•) and mean weight of age 4 sprat during 1974-2004 (•) 

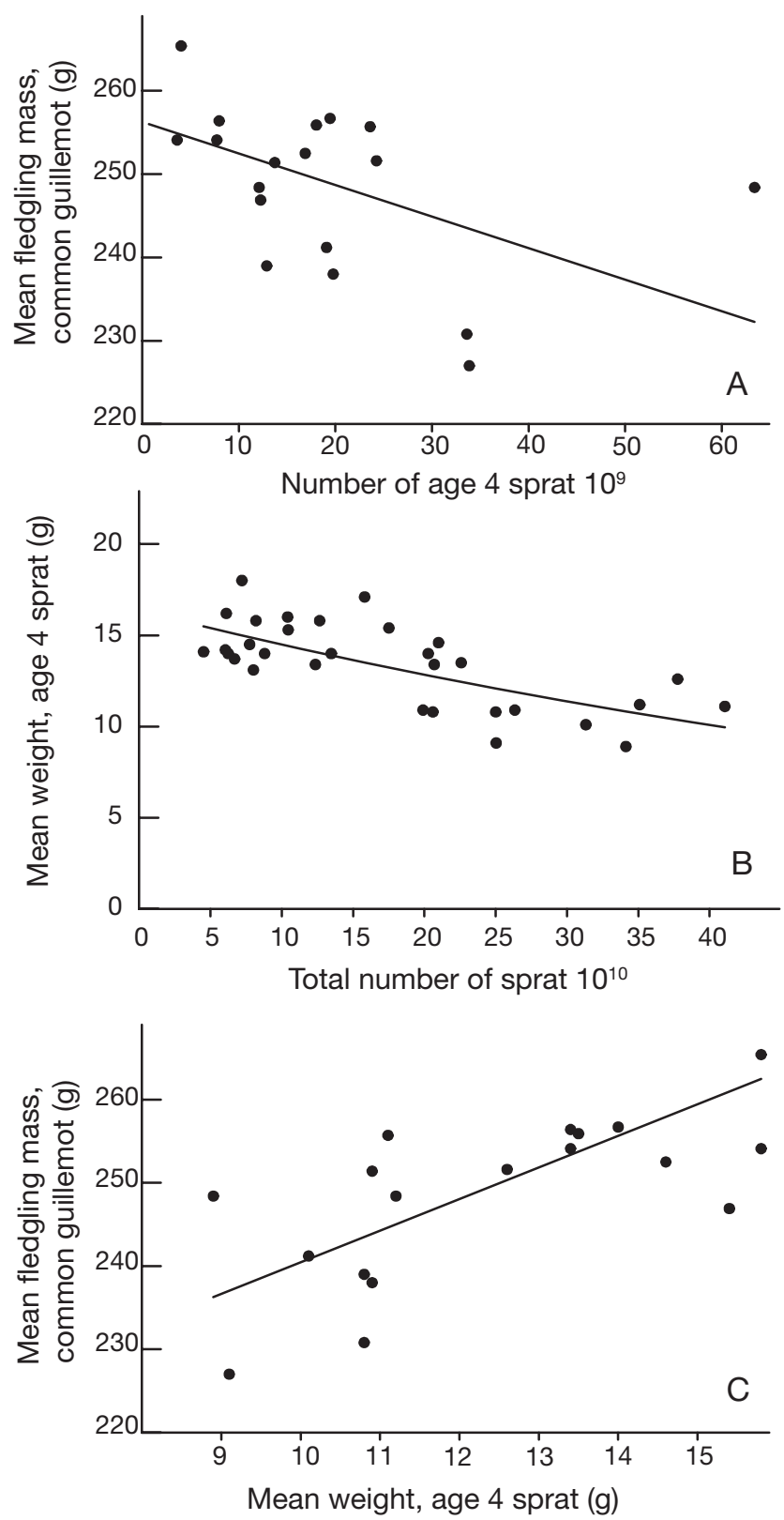

Fig. 3. Uria aalge and Sprattus sprattus. Relationships between (A) common guillemot mean fledging body mass and sprat abundance (age 4), (B) mean weight of age 4 sprat and total sprat abundance and (C) common guillemot fledging body mass and mean weight of age 4 sprat, 1974-2004

\section{DISCUSSION}

In Österblom et al. (2001), we reported high chick fledging mass during the early 1990s, which corresponded to the fledging mass in the 1970s, indicating good conditions; thereafter, weights began to drop (Österblom et al. 2001, this study). This was surprising, as it coincided with an increase in the abundance of

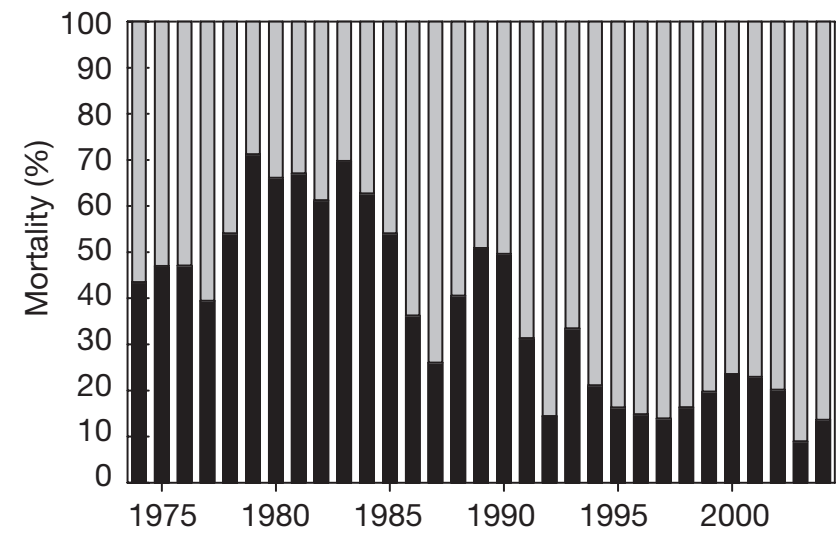

Fig. 4. Sprattus sprattus. Relative mortality of fishing (grey bars) and cod predation (black bars) on adult sprat

common guillemot's main prey (sprat) during the 1990s, following the cod stock collapse (ICES 2005a, this study). However, sprat abundance decreased from the end of the 1990s and common guillemot fledging mass recently increased, thus confirming this unexpected, reverse response to sprat stock size.

Fledging mass was significantly positively correlated with mean weight of sprat. Hedgren (1976) and Lyngs \& Durinck (1998) previously illustrated the importance of sprat in common guillemot diet in the Baltic Sea, and our results, which demonstrate that the fledging body mass of chicks is correlated with the mean weight of sprat, may confirm that in this area the breeding success of common guillemots is dependent on sprat as a food source. The fat content of herring (the other potential prey for common guillemots) in the Baltic Sea is significantly lower than that of sprat (Hjelm et al. 2006); thus, common guillemots have limited capacity to switch to alternative suitable prey during periods of low sprat abundance or when sprat become lean.

The common guillemot is specialized in feeding on fish with high energy density, and it has a fast, relatively inefficient and inflexible digestive process (Hilton et al. 2000). Digestive efficiency in seabirds decreases with decreasing lipid (i.e. energy) content (Brekke \& Gabrielsen 1994), and energy content is highly correlated with sprat weight (Hilton et al. 2000). A range of pelagic fish species suitable for seabirds in, e.g., the North Sea (Hislop et al. 1991) and Gulf of Alaska (Anthony et al. 2000) show positive correlations between energy content and size-at-age. The variation in sprat weight observed in the Baltic Sea is thus presumably also correlated with energy content. High sprat abundances lead to a decrease in its quality as food to common guillemots, and hence to reduced chick fledging mass. This study thus indicates that pursuit-diving seabirds are also sensitive to variation in food quality (cf. Wanless et al. 2005). 
Decreasing mean weights in another Baltic Sea clupeid (herring) during the 1990s has been attributed to either salinity-derived changes that affected zooplankton prey biomass (a bottom-up mechanism, where decreasing salinities negatively affect the marine copepod Pseudocalanus elongatus, the main prey for herring in the area; Möllmann et al. 2003, Rönkkönen et al. 2004) or increased competition with sprat (a topdown mechanism; Casini et al. 2006). However, available evidence suggests that the deteriorated condition of sprat during the 1990s was mainly due to increased sprat abundance, which intensified the intra- and inter-specific competition in the clupeid population and resulted in a density-dependent decrease in clupeid growth (Casini et al. 2006).

The fishery can affect the sprat stock both directly, by fishing for sprat, and indirectly, by controlling the dynamics of its key predator, cod. The drop in cod abundance from the mid-1980s was due to increased fishing, combined with decreased recruitment owing to oxygen depletion in the Baltic main deep basins (Bagge \& Thurow 1994, ICES 2005a). The increase in sprat from the 1990s was principally linked with reduced predation, as sprat is the main prey for cod in the Baltic (Horbowy 1996, ICES 2005b). Currently, sprat stock dynamics are principally driven by fishing effort and environmentally mediated recruitment variation. The cod stock is held at current low levels by a high fishing pressure, a lack of suitable spawning areas (i.e. low salinity and oxygen deficiency in the main Baltic basins), and possibly clupeid predation on cod eggs (ICES 2005a,b). It has been proposed that sprat predation on cod eggs, or cod predation on sprat, can lead to shifts between a clupeid- or cod-dominated Baltic food-web (Rudstam et al. 1994). However, a reduction in fishing mortality is considered necessary for the cod stock to rebuild (ICES 2005a). Differences in management, acting on sprat, herring or cod, could directly or indirectly alter the sprat stock, and produce different cascading effects on the common guillemot populations through regulation of clupeid competition and growth.

This study provides a unique illustration of a consistent, short- and long-term relationship between common guillemot fledging body mass and mean weight of sprat. The mean weight of sprat has changed due to, e.g., changes in sprat abundance, which in turn has been affected by cod predation and the commercial fishery for sprat. The observed effects on common guillemot, a piscivorous seabird, were mediated by fisheries- and environmentally driven changes in the quantity and quality of its food source. Management targets for the sustainable use of marine resources should not be based solely on the priorities of the fisheries sector, if a healthy ecosystem is desired. How- ever, the complex trophic interactions described for this relatively simple ecosystem illustrate the substantial challenges that lie ahead.

Acknowledgements. The Swedish Bird Ringing Centre kindly provided us access to common guillemot data collected by hundreds of volunteers. We are grateful to the referees for valuable comments on the manuscript. This study was funded by WWF Sweden and the Erik Rudstedt Lindberg foundation for bird research. H.Ö. was financed by Mistra. M.C. was funded by Oscar och Lili Lamms Minne foundation.

\section{LITERATURE CITED}

Ainley DG (1977) Feeding methods in seabirds: a comparison of polar and tropical communities in the eastern Pacific Ocean. In: Llano GA (ed) Adaptations within Antarctic ecosystems. Gulf Publishing, Houston, TX, p 669-685

Ainley DG, Sydeman WJ, Norton J (1995) Upper trophic level predators indicate interannual negative and positive anomalies in the California Current food web. Mar Ecol Prog Ser 118:69-79

Anker-Nilssen T, Barrett RT, Krasnov JV (1997) Long- and short-term responses of seabirds in the Norwegian and Barents Seas to changes in stocks of prey fish. In: Forage fishes in marine ecosystems. Alaska Sea Grant College Program Report 97-01, University of Alaska, Fairbanks, p 683-698

Anthony JA, Roby DD, Turco KR (2000) Lipid content and energy density of forage fishes from the Northern Gulf of Alaska. J Exp Mar Biol Ecol 248:53-78

Axenrot T, Hansson S (2003) Predicting herring recruitment from young-of-the-year densities, spawning stock biomass, and climate. Limnol Oceanogr 48:1716-1720

Bagge O, Thurow F (1994) The Baltic cod stock: fluctuations and possible causes. ICES Mar Sci Symp 198:254-268

Bertram DF, Mackas DL, McKinnell SM (2001) The seasonal cycle revisited: interannual variation and ecosystem consequences. Prog Oceanogr 49:283-307

Bradstreet MSW, Brown RGB (1985) Feeding ecology of the Atlantic Alcidae. In: Nettleship DN, Birkhead TR (eds) The Atlantic Alcidae: the evolution, distribution and biology of the auks inhabiting the Atlantic Ocean and adjacent water areas. Academic Press, London, p 263-318

Brekke B, Gabrielsen GW (1994) Assimilation efficiency of adult kittiwakes and Brünnich's guillemots fed capelin and Arctic cod. Polar Biol 14:279-284

Cairns DK (1987) Seabirds as indicators of marine food supplies. Biol Oceanogr 5:261-271

Casini M, Cardinale M, Hjelm J (2006) Inter-annual variation of herring (Clupea harengus) and sprat (Sprattus sprattus) condition in the central Baltic Sea: what gives the tune? Oikos 112:638-650

Davoren GK, Montevecchi WA (2003) Signals from seabirds indicate changing biology of capelin stocks. Mar Ecol Prog Ser 258:253-261

Furness RW (2003) Impacts of fisheries on seabird communities. Sci Mar 67(Suppl 2):33-45

Gjerdrum C, Vallée AMJ, St. Clair CC, Bertram DF, Ryder JL, Blackburn GS (2003) Tufted puffin reproduction reveals ocean climate variability. Proc Natl Acad Sci USA 100: 9377-9382

Hedgren S (1976) On the food of the guillemot Uria aalge at the island of Stora Karlsö, in the Baltic Sea. Var Fagelvarld 35:287-290 
Hedgren S (1979) Seasonal variation in fledging weight of guillemots Uria aalge. Ibis 121:356-361

Hilton GM, Furness RW, Houston DC (2000) The effects of diet switching and mixing on digestion in seabirds. Funct Ecol 14:145-154

Hislop JRG, Harris MP, Smith JGM (1991) Variation in the calorific value and total energy content of the lesser sandeel (Ammodytes marinus) and other fish preyed on by seabirds. J Zool 224:501-517

Hjelm J, Hultgren M, Cardinale M (2006) Water uptake in herring (Clupea harengus) and sprat (Sprattus sprattus) as a function of area, salinity and fat content. Fish Res 81:94-99

Horbowy J (1996) The dynamics of Baltic fish stocks on the basis of a multispecies stock-production model. Can J Fish Aquat Sci 53:2115-2125

ICES (2005a) Report of the Baltic Fisheries Assessment Working Group (WGBFAS), 12-21 April 2005. Hamburg, Germany. ICES Counc Meet 2005/ACFM:19, Ref. H

ICES (2005b) Report of the Study Group on Multispecies Assessment in the Baltic (SGMAB), 13-17 June 2005, Riga, Latvia. ICES Counc Meet 2005/H:06

Lyngs P (1992) Ynglefuglene på Græsholmen 1925-90. Dan Orn Foren Tidsskr 86:1-93 (in Danish with English summary)

Lyngs P, Durinck J (1998) Diet of Guillemots Uria aalge in the central Baltic Sea. Dansk Orn Foren Tidsskr 92:197-200

MacKenzie BR, Köster F (2004) Fish production and climate: sprat in the Baltic Sea. Ecology 85:784-794

Möllmann C, Köster FW (2002) Population dynamics of calanoid copepods and the implications of their predation by clupeid fish in the Central Baltic Sea. J Plankton Res 24: 959-977

Editorial responsibility: Otto Kinne (Editor-in-Chief), Oldendorf/Luhe, Germany
Möllmann C, Kornilovs G, Fetter M, Köster FW, Hinrichsen $\mathrm{HH}$ (2003) The marine copepod, Pseudocalanus elongatus, as a mediator between climate variability and fisheries in the Central Baltic Sea. Fish Oceanogr 12:360-368

Oro D, Furness RW (2002) Influence of food availability and predation on survival of Kittiwakes. Ecology 83: $2516-2528$

Oro D, Cam E, Pradel R, Martínez-Abraín A (2003) Influence of food availability on demography and local population dynamics in a long-lived seabird. Proc R Soc Lond Ser B 271:387-396

Österblom H, Olsson O (2002) Changes in feeding behaviour and reproductive success in the Common Guillemot Uria aalge on the island of Stora Karlsö. Ornis Svecica 12:53-62

Österblom H, Bignert A, Fransson T, Olsson, O (2001) A decrease in fledging body mass in common guillemot Uria aalge chicks in the Baltic Sea. Mar Ecol Prog Ser 224: 305-309

Rönkkönen S, Ojaveer E, Raid T, Viitasalo M (2004) Longterm changes in Baltic herring (Clupea harengus membras) growth in the Gulf of Finland. Can J Fish Aquat Sci 61:219-229

Rudstam LG, Aneer G, Hildén, M (1994) Top-down control in the pelagic Baltic ecosystem. Dana 10:105-129

Sydeman WJ, Penniman JF, Penniman TM, Pyle P, Ainley DG (1991) Breeding performance in the western gull: effects of parental age, timing of breeding and year in relation to food availability. J Anim Ecol 60:135-149

Wanless S, Harris MP, Redman P, Speakman JR (2005) Low energy values of fish as a probable cause of a major seabird breeding failure in the North Sea. Mar Ecol Prog Ser 294:1-8

Submitted: November 24, 2005; Accepted: April 20, 2006 Proofs received from author(s): September 20, 2006 